University of Nebraska - Lincoln

DigitalCommons@University of Nebraska - Lincoln

Agronomy \& Horticulture -- Faculty Publications

Agronomy and Horticulture Department

2004

\title{
Distribution of Legumes along Gradients of Slope and Soil Electrical Conductivity in Pastures
}

\author{
John A. Guretzky \\ University of Nebraska-Lincoln, jguretzky2@unl.edu \\ Kenneth J. Moore \\ lowa State University, kjmoore@iastate.edu \\ C. Lee Burras \\ lowa State University \\ E. Charles Brummer \\ lowa State University
}

Follow this and additional works at: https://digitalcommons.unl.edu/agronomyfacpub

Part of the Plant Sciences Commons

Guretzky, John A.; Moore, Kenneth J.; Burras, C. Lee; and Brummer, E. Charles, "Distribution of Legumes along Gradients of Slope and Soil Electrical Conductivity in Pastures" (2004). Agronomy \& Horticulture -Faculty Publications. 544.

https://digitalcommons.unl.edu/agronomyfacpub/544

This Article is brought to you for free and open access by the Agronomy and Horticulture Department at DigitalCommons@University of Nebraska - Lincoln. It has been accepted for inclusion in Agronomy \& Horticulture -Faculty Publications by an authorized administrator of DigitalCommons@University of Nebraska - Lincoln. 


\title{
PASTURE MANAGEMENT
}

\author{
Distribution of Legumes along Gradients of Slope and \\ Soil Electrical Conductivity in Pastures
}

\author{
John A. Guretzky,* Kenneth J. Moore, C. Lee Burras, and E. Charles Brummer
}

\begin{abstract}
Legumes establish and persist on backslope landscape positions but fail on summits and toeslopes in southeastern Iowa pastures, suggesting that these pastures be managed site specifically. Visual delineation of landscape positions, however, can be difficult, and characterization of spatial variability through soil sampling is expensive. Creation of digital elevation models (DEM) and apparent soil electrical conductivity $\left(\mathrm{EC}_{\mathrm{a}}\right)$ mapping are inexpensive alternatives to describing field conditions. Our objective was to examine the relationship of DEM-derived slope, soil $\mathrm{EC}_{\mathrm{a}}$, and legume distribution in pastures. We examined these relationships across four 1.4-ha pastures. Each pasture was divided into 0.46 -ha plots that were assigned one of three stocking treatments: continuous, rotational, and nongrazed. We found that legumes, as a percentage of pasture cover, were greatest at 15 to $20 \%$ slopes and intermediate values of soil $\mathbf{E C}_{\mathbf{a}}$. The absolute $\mathbf{E C}_{\mathrm{a}}$ value at which legumes were maximized varied by plot within each stocking system and year $\mathbf{E C}_{\mathrm{a}}$ was measured. When $\mathbf{E C}_{\mathrm{a}}$ was standardized by pasture and year, however, a nonlinear response curve explained 23 to $42 \%$ of the variation of legume cover across the plots. Grazing reduced competition from smooth brome (Bromus inermis Leyss.) and reed canarygrass (Phalaris arundinacea $\mathbf{L}$ ). These grasses dominated at 0 to $8 \%$ slopes and where $\mathrm{EC}_{\mathrm{a}}$ was either low or high in value. We concluded that slope and soil $\mathrm{EC}_{\mathrm{a}}$ data are useful in identifying sites where legumes are successful in pastures and showed potential for use in site-specific management of pastures.
\end{abstract}

Tegumes improve the quality and production of pasture swards. Through a symbiotic relationship with rhizobium bacteria, legumes fix atmospheric N. The decomposition of legume leaf residues, roots, and nodules increases soil $\mathrm{N}$, and $\mathrm{N}$ transfer to coexisting grasses increases sward productivity and quality of forage grasses (Heichel et al., 1985). Legumes are also greater in crude protein than grasses (Van Soest, 1982), and their incorporation with cool-season grasses improves the seasonal distribution of dry matter and nutrients in pastures (Sleugh et al., 2000).

Landscape position in pastures affects the distribution and abundance of legumes in southeastern Iowa pastures. Establishment, diversity, and persistence of legumes are greater on backslope landscape positions than summit or toeslope positions (Harmoney et al., 2001). As a proportion of total dry matter, legume production was $161 \mathrm{~g} \mathrm{~kg}^{-1}$ on backslopes, $62 \mathrm{~g} \mathrm{~kg}^{-1}$ on summits, and $7 \mathrm{~g} \mathrm{~kg}^{-1}$ on toeslopes. Competition from grasses

J.A. Guretzky, K.J. Moore, C.L. Burras, and E.C. Brummer, Dep. of Agron., Iowa State Univ., Ames, IA 50011-1010. Received 7 May 2003. *Corresponding author (John.A.Guretzky@erdc.usace.army.mil).

Published in Agron. J. 96:547-555 (2004).

(C) American Society of Agronomy

677 S. Segoe Rd., Madison, WI 53711 USA limits legume establishment and persistence on summit and toeslope positions (Guretzky et al., 2004; Harmoney et al., 2001).

Visual delineation of where one landscape position ends and another begins in pastures can be difficult. Spatial information about fields or pastures are displayed, stored, and analyzed more effectively with a geographic information system (GIS). A GIS allows users to create a DEM for fields or pastures of interest that displays spatial data three dimensionally and enables users to calculate topographic derivatives such as slope, aspect, flow accumulation, and wetness index (Burrough and McDonnell, 1998). Digital elevation models also allow maps of plant, soil, and environmental attributes to be overlayed to improve and aid visual or statistical comparisons.

Scientists have examined the relationship of DEMderived attributes such as slope, flow accumulation, and wetness index with grain yields of corn (Zea mays L.) and soybean [Glycine max (L.) Merr.], soil properties, and distribution of drainage classes in fields. Kravchenko and Bullock (2000) used a DEM to examine the relationship between topographic attributes such as slope and flow accumulation with soil properties and corn and soybean grain yield. Moore et al. (1993) used a DEM to examine the relationship between topographic attributes and several soil properties.

Field-scale mapping of soil $\mathrm{EC}_{\mathrm{a}}$ also may be used to characterize the spatial variation of soil properties correlated with site productivity (Johnson et al., 2001; Kitchen et al., 1999, 2003). Soil $\mathrm{EC}_{\mathrm{a}}$ is a field-based measure of the electrical conductivity of bulk soil and is primarily a function of soil salinity, saturation percentage, water content, and bulk density (Corwin and Lesch, 2003). It is determined by sensors that use either electrical resistivity or electromagnetic induction (Corwin and Lesch, 2003; Sudduth et al., 2003). The Veris 3100 (Veris Technol., Salina, KS) and the EM-38 (Geonics Limited, Mississauga, ON, Canada) are commercial sensors that use electrical resistivity and electromagnetic induction, respectively, to measure $\mathrm{EC}_{\mathrm{a}}$ (Corwin and Lesch, 2003; Sudduth et al., 2003). Mapping of $\mathrm{EC}_{\mathrm{a}}$ is advantageous because it minimizes the number of soil samples required to describe overall field conditions (Johnson et al., 2001). In Illinois, soil $\mathrm{EC}_{\mathrm{a}}$ was least in well- and moderately well-drained soils and greatest in poorly and somewhat poorly drained soils (Kravchenko et al.,

Abbreviations: AUM, animal unit month; DEM, digital elevation model; $\mathrm{EC}_{\mathrm{a}}$, apparent electrical conductivity; GIS, geographic information system; GPS, global positioning system. 
2002). In eastern Colorado, greatest $\mathrm{EC}_{\mathrm{a}}$ values were characteristic of eroded surfaces and lower crop yields (Johnson et al., 2001).

Digital elevation models and soil $\mathrm{EC}_{\mathrm{a}}$ mapping have not been used for site-specific management of pastures. The objective in our study was to measure and characterize the abundance and distribution of legumes in pastures along gradients of DEM-derived slope and soil $E_{a}$. We expected slope and soil $E_{a}$ to affect the distribution of legumes indirectly through their relationship with soil properties correlated with productivity of grasses in pastures. We determined plant species composition and collected elevation and $\mathrm{EC}_{\mathrm{a}}$ data across four replicated pastures, each of which were divided into plots assigned one of three different stocking systems. This information was integrated into a GIS where we created a DEM and quantified the relationship among the percentage of legumes, slope, and soil $\mathrm{EC}_{\mathrm{a}}$.

\section{MATERIALS AND METHODS}

We conducted the experiment at the Iowa State University Rhodes Research Farm $\left(41^{\circ} 52^{\prime}\right.$ N, 93 $90^{\prime} \mathrm{W}$ ) in pastures described by Harmoney et al. (2001). In 1995, a mixture of legumes was frost-seeded across four 1.4 ha-pasture replicates. The legumes used were alfalfa (Medicago sativa $\mathrm{L}$.), biennial yellow sweetclover [Melilotus officinalis (L.) Pall], biennial white sweetclover (Melilotus alba Medic.), birdsfoot trefoil (Lotus corniculatus L.), white clover (Trifolium repens L.), red clover (Trifolium pratense L.), kura clover (Trifolium ambiguum Bieb.), cicer milkvetch (Astragalus cicer L.), berseem clover (Trifolium alexandrinum L.), striate lespedeza [Kummerowia striata (Thunb.) Schindler], and annual white sweetclover (Melilotus alba Medic.). The legumes were resown in the grass sod in 1996 because of poor establishment in the first seeding (Harmoney et al., 2001).

Each pasture replicate was divided into 0.46-ha plots, with each plot being assigned one of three stocking treatments: continuous, rotational, and nongrazed. Each plot was similar in that they each contained five landscape positions: a summit, backslope, toeslope, opposite backslope, and opposite summit. Two of the replicates (six plots) contained backslopes with north-south-facing aspects, and two replicates (six plots) had backslopes with east-west-facing aspects. Aspect did not affect legume production in these pastures (Harmoney et al., 2001). The effects of aspect or landscape position were not examined in this study.

Grazing treatments began in 1996. From 1996 to 1998, grazing began at the end of May and continued until early to midAugust within the continuously stocked plots. Each of the rotationally stocked plots was grazed for $4 \mathrm{~d}$ in mid-May, early July, and late October. Stocking rates were similar among the rotational and continuous stocking treatments: 9.4 animal unit months (AUMs) ha ${ }^{-1}$ within the rotational system and 10.1 AUMs ha ${ }^{-1}$ within the continuous system. An AUM is equivalent to the amount of dry forage that a 454-kg cow, dry or with a calf less than 6 mo old, who eats about $12 \mathrm{~kg}$ of dry matter per day, will consume in one month (Iowa State Univ. Ext., 1998). Nongrazed plots were not grazed, but dead vegetation was mowed in mid-November (Harmoney et al., 2001).

From 1999 to 2001, continuously stocked paddocks were grazed by two nonlactating beef cows for $28 \mathrm{~d}$ in May and June, $21 \mathrm{~d}$ in July, and $14 \mathrm{~d}$ in October. Rotationally stocked paddocks were grazed with eight to nine cows for $4 \mathrm{~d}$ in May, seven to eight cows for $4 \mathrm{~d}$ in July, and six to seven cows for
$4 \mathrm{~d}$ in October. Cows were placed within the continuously and rotationally stocked paddocks on the same date and were removed from the continuously stocked paddocks when residue heights for the majority of the herbage was $<13 \mathrm{~cm}$. Cows were removed from the rotationally stocked paddocks after the 4-d period of each grazing event. Stocking density within the rotational stocking method was intended to be heavy enough to reduce selective grazing, remove the majority of forage within a 4-d span, and increase the period of rest between grazing events.

\section{Terrain Analysis and Vegetation Sampling}

In 1999, we used a survey grade global position system (GPS) to determine elevation throughout each plot. These data were incorporated into a GIS, ArcView 3.2 (ESRI, Redlands, CA), and used to create a DEM for each pasture. We used spline methods in ArcView to develop a base elevation map for each pasture because these methods appeared to produce the smoothest maps. Parameters were weight $=0.1$, number of points $=12$, type $=$ regularized, and output grid size $=1 \mathrm{~m}^{2}$ for the spline method. From the base elevation map, we derived slope using the Spatial Analyst extension in ArcView.

Flow accumulation and wetness index were also derived in ArcView using the Hydrologic Modeling extension. These measures are based on how water and sediment flow across a landscape (Burrough and McDonnell, 1998; Moore et al., 1993). Flow accumulation is a measure of the cumulative amount of material that passes through each grid cell and is based on elevation and overland flow direction. Flow accumulation is usually displayed on a log scale, and cells with greater flow accumulation are areas of concentrated flow and may indicate stream channels (Burrough and McDonnell, 1998). Wetness index is an index of moisture retention and is calculated as $\ln [$ specific catchment area/tan(slope)] (Burrough and McDonnell, 1998; Moore et al., 1993).

Soil $\mathrm{EC}_{\mathrm{a}}$ was measured and georeferenced on 4 Sept. 2000 and 28 Aug. 2001 using an EM-38 (Geonics Limited, Mississauga, $\mathrm{ON}$, Canada). The $\mathrm{EC}_{\mathrm{a}}$ data were determined in each plot and obtained at $\approx 315$ points per plot. Inverse distance weighting was used within ArcView to interpolate maps of $\mathrm{EC}_{\mathrm{a}}$ because it did not require semivariogram modeling (Burrough and McDonnell, 1998). Parameters chosen were nearest neighbors $=12$, power $=2$, and no barriers.

Species composition of the four 1.4-ha pastures was determined using a percentage cover method (Daubenmire, 1968). In each 0.46-ha plot, we recorded the percentage of aerial cover for each plant species within approximately one hundred $0.2-\mathrm{m}^{2}$ sample quadrats. We calculated the relative percentage of cover for each species on a 0 to $100 \%$ scale because the total percentage of aerial cover for all species could sum to $>$ or $<100 \%$ within each quadrat due to overlapping of species or gaps between plant species. Quadrats were randomly distributed and sampled each May and July of 2000 and 2001. Following georeferencing of each sample location with a GPS, we incorporated the vegetation and sample position data into ArcView. In ArcView, the vegetation point data were overlayed with the elevation, slope, wetness index, flow accumulation $(\log )$, and $\mathrm{EC}_{\mathrm{a}}$ maps, and corresponding values from these variables were assigned to each vegetation sample point. This information was then exported from ArcView for statistical analysis.

\section{Statistical Analysis}

The mean, maximum, minimum, standard deviation, and skewness were determined for elevation, slope, wetness index, 
flow accumulation (log), and $\mathrm{EC}_{\mathrm{a}}$ variables associated with the vegetation sampling points using the Univariate procedure in SAS (Statistical Analysis Software, Version 8.2, SAS Inst., Cary, NC). Vegetation points with an elevation, slope, or $\mathrm{EC}_{\mathrm{a}}$ value that was greater than 2.5 standard deviations from the mean for each of these variables were removed from the data set. Approximately 300 outliers were removed from the data set; outliers were not removed based on extreme vegetative characteristics. Following removal of elevation, slope, and soil $\mathrm{EC}_{\mathrm{a}}$ outliers, these variables were normally distributed (Table 1).

We examined the relationship of legumes and the dominant grasses in these pastures across the gradients of slope and soil $\mathrm{EC}_{\mathrm{a}}$ using the $\approx 4500$ remaining samples. The large number of vegetation samples encouraged us to divide the range of slope and $\mathrm{EC}_{\mathrm{a}}$ values into 6 and 10 classes and limit our regression analyses to just slope and soil $\mathrm{EC}_{\mathrm{a}}$ variables. Slope was divided into six classes so that a high number of observations occurred at the low and high ends of the slope range. Soil $\mathrm{EC}_{\mathrm{a}}$ was divided into a greater number of classes because more classes better demonstrated the vegetation- $\mathrm{EC}_{\mathrm{a}}$ relationship and improved the fit of nonlinear regression curves. The average percentage of cover of legumes, smooth brome, and reed canarygrass was calculated from the vegetation samples for each slope and $\mathrm{EC}_{\mathrm{a}}$ class within each stocking method and pasture replicate. Smooth brome and reed canarygrass were the dominant grasses competing with legumes in these pastures. The percentage of legume cover was calculated by summing the percentage of cover of all legume species within each slope and $\mathrm{EC}_{\mathrm{a}}$ class.

Linear regressions were computed between legume cover and slope across the four plots of each stocking system. Separate regressions were performed by plot within each stocking system between the percentage of legume cover and $\mathrm{EC}_{\mathrm{a}}$ measured in 2000 and 2001 because regression analyses performed across all plots within each stocking system were not significant (data not shown). When the relationship between the percentage of legume cover and $\mathrm{EC}_{\mathrm{a}}$ was nonlinear, we log-transformed the legume cover data. When a response curve is fit to the logarithm of original abundance data, a Gaussian response curve is actually fit to the original abundance data (ter Braak and Looman, 1995).

The Gaussian response curve had the formula:

$$
z=c \exp \left[-0.5(x-u)^{2} / t^{2}\right]
$$

where

$z$ is the original abundance value

$c$ is the species maximum abundance

$u$ is its optimum, the value of $x$ that gives the maximum abundance

$t$ is its tolerance, a measure of ecological amplitude

Log transformation of the original abundance data eliminated negative values in the predicted response curve and enabled the derivation of the optimum $\mathrm{EC}_{\mathrm{a}}$ value that gave the maximum percentage of legume cover, $u=-b_{1} / 2 b_{2}$; the
Table 1. Mean, standard deviation, minimum, maximum, and skewness for elevation, slope, wetness index, flow accumulation, and apparent soil electrical conductivity $\left(\mathrm{EC}_{\mathrm{a}}\right)$ measured in 2000 and 2001 in pasture replicates at Rhodes, IA. Values correspond to vegetation sampling points randomly distributed and georeferenced across four pasture replicates and three stocking systems (12 plots) in May and July of 2000 and 2001 $(n=4467)$.

\begin{tabular}{lrcccr}
\hline Variable & Mean & SD & Minimum & Maximum & Skewness \\
\hline Elevation, m & $\mathbf{3 0 0 . 6}$ & $\mathbf{3 . 0 8}$ & $\mathbf{2 9 2 . 7}$ & $\mathbf{3 0 7 . 1}$ & $-\mathbf{0 . 1 7 5}$ \\
Slope, \% & $\mathbf{1 0 . 3}$ & $\mathbf{4 . 0 8}$ & $\mathbf{0 . 1}$ & $\mathbf{2 8 . 8}$ & $\mathbf{0 . 2 3 7}$ \\
Wetness index & 4.2 & $\mathbf{1 . 7 1}$ & $\mathbf{0}$ & $\mathbf{1 2 . 4}$ & $-\mathbf{0 . 2 2 4}$ \\
Flow accumulation, log $^{2.5}$ & $\mathbf{1 . 3 1}$ & $\mathbf{0}$ & $\mathbf{8 . 4}$ & $\mathbf{0 . 1 5 6}$ \\
Soil EC $_{\mathrm{a}}$ 2000, mS m $^{-1}$ & $\mathbf{2 9 . 2}$ & $\mathbf{5 . 4 2}$ & $\mathbf{1 8 . 9}$ & $\mathbf{4 6 . 9}$ & $-\mathbf{0 . 3 5 1}$ \\
Soil EC $_{\mathrm{a}}$ 2001, $\mathrm{mS} \mathrm{m}^{-1}$ & $\mathbf{4 0 . 6}$ & $\mathbf{7 . 6 2}$ & $\mathbf{2 2 . 9}$ & $\mathbf{6 0 . 4}$ & $\mathbf{0 . 2 7 5}$ \\
\hline
\end{tabular}

maximum legume cover at the optimum, $c=\exp \left(b_{0}+b_{1} u+\right.$ $b_{2} u^{2}$ ); and its tolerance, $t=1 / \sqrt{ }\left(-2 b_{2}\right)$ (ter Braak and Looman, 1995).

We also fit a Gaussian response curve to the relationship between log-transformed legume cover data and soil $\mathrm{EC}_{\mathrm{a}}$ standardized within each pasture. This curve was fit across all plots within each stocking system. We standardized $\mathrm{EC}_{\mathrm{a}}$ by ranking each of the original $10 \mathrm{EC}_{\mathrm{a}}$ classes within each pasture replicate from 0 to 9 . The data were not log-transformed when linear regressions were computed between soil $\mathrm{EC}_{\mathrm{a}}$ and the percentage of legume, smooth brome, and reed canarygrass cover. All regression analyses were performed using the REG procedure in SAS (Statistical Analysis Software, Version 8.2, SAS Inst., Cary, NC). We concluded that the relationship between legume cover and soil $\mathrm{EC}_{\mathrm{a}}$ was nonlinear if the Guassian response curve improved the fit of the regression over that of the linear response function and was significant at $P<0.10$.

\section{RESULTS}

\section{Topographic Characteristics}

The pastures are on rolling landscapes with slopes as steep as $29 \%$. The minimum, maximum, and mean for elevation, slope, wetness index, flow accumulation, and $\mathrm{EC}_{\mathrm{a}}$ measured in 2000 and 2001 were similar among stocking systems. On average, across pastures and stocking systems, elevation decreased $15 \mathrm{~m}$ from summits to toeslopes (Table 1). Soil EC $\mathrm{E}_{\mathrm{a}}$ measured in 2000 and 2001 was negatively correlated with elevation (Table 2). On average, across pastures and stocking systems, soil $\mathrm{EC}_{\mathrm{a}}$ increased down the hillslope from summit positions to toeslope positions by $28.0 \mathrm{mS} \mathrm{m}^{-1}$ in 2000 and 37.5 $\mathrm{mS} \mathrm{m}^{-1}$ in 2001 (Table 1). Soil $\mathrm{EC}_{\mathrm{a}}$ was also positively correlated with wetness index and flow accumulation (Table 2).

Table 2. Pearson correlation coefficients $(r)$ computed for elevation, slope, soil $\mathbf{E C}_{\mathrm{a}}$ measured in 2000 and 2001 , wetness index, and flow accumulation variables among vegetation samples in pastures at Rhodes, IA $(P<0.05 ; n=4467)$.

\begin{tabular}{|c|c|c|c|c|c|c|}
\hline & Elevation & Slope & $\begin{array}{c}\text { Soil EC } \mathbf{E C}_{\mathrm{a}} \\
2000\end{array}$ & $\begin{array}{c}\text { Soil EC } \\
2001\end{array}$ & $\begin{array}{c}\text { Wetness } \\
\text { index }\end{array}$ & $\begin{array}{c}\text { Flow } \\
\text { accumulation }\end{array}$ \\
\hline Elevation & 1.00 & -0.32 & -0.28 & -0.21 & -0.14 & -0.24 \\
\hline Slope & & 1.00 & 0.39 & 0.25 & -0.15 & -0.03 \\
\hline Soil EC a $_{\mathrm{a}} 2000$ & & & 1.00 & 0.79 & 0.13 & 0.16 \\
\hline Soil EC $\mathrm{CC}_{\mathrm{a}} 2001$ & & & & 1.00 & 0.14 & 0.30 \\
\hline Wetness index & & & & & 1.00 & 0.74 \\
\hline Flow accumulation & & & & & & 1.00 \\
\hline
\end{tabular}



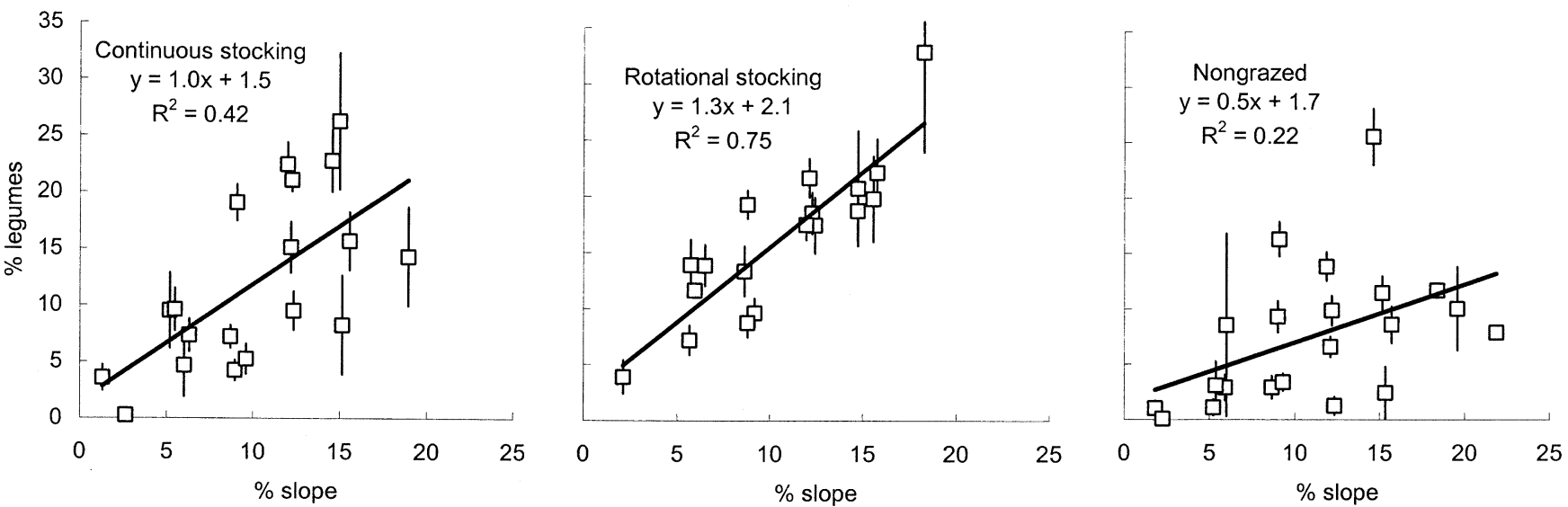

Fig. 1. Stocking system (continuous, rotational, and nongrazed) effects on the relationship between the percentage of cover consisting of legumes and slope $(\%)$ in pastures at Rhodes, IA. The range of slope was divided into six classes within each of the four pasture replicates. Legume cover was averaged within each slope class of the four plots of each stocking system. Some slope classes were not represented within all four plots of each stocking system $(n \approx 24)$. Points and bars represent the mean \pm standard error.

\section{Slope and Legumes}

Legumes, as a percentage of cover, increased positively as a function of slope (Fig. 1). The rate of increase with slope, however, differed between stocking systems. Legumes increased at a greater rate within the rotational stocking method than within the continuous or nongrazed stocking methods, and the rate of increase of legume cover with slope was also greater within continuous stocking method than the nongrazed method.

\section{Apparent Soil Electrical Conductivity and Legumes}

A nonlinear response occurred within 9 of the 12 plots between the percentage of legume cover and soil
$\mathrm{EC}_{\mathrm{a}}$ measured in 2000 and within 7 of the 12 plots between the percentage of legume cover and soil $\mathrm{EC}_{\mathrm{a}}$ measured in 2001 (Table 3). Legume cover showed a negative linear response to soil $\mathrm{EC}_{\mathrm{a}}$ measured in 2000 in Plot 4 within the rotational and nongrazed systems, a positive linear response to soil $\mathrm{EC}_{\mathrm{a}}$ measured in 2001 in Plots 1 and 2 of the rotational stocking system, and a negative linear response to soil $\mathrm{EC}_{\mathrm{a}}$ measured in 2001 in Plot 4 of the nongrazed system (Table 3 ).

The optimum $\mathrm{EC}_{\mathrm{a}}(u)$ at which legumes were maximized varied among the plots and was greater when regressions were performed with soil $\mathrm{EC}_{\mathrm{a}}$ measured in 2001 than when measured in 2000 (Table 3). Legume cover increased to an optimum $\mathrm{EC}_{\mathrm{a}}$ before declining, ranging among the plots from 28.7 to $38.0 \mathrm{mS} \mathrm{m}^{-1}$ in

Table 3. Distribution of legumes along a gradient of soil electrical conductivity $\left(\mathbf{E C}_{\mathrm{a}}\right)$, measured in 2000 and 2001 . A linear regression or a nonlinear response curve was fit between the percentage of legume cover and soil $\mathbf{E C}_{\mathrm{a}}$ by plot within each stocking system. When a nonlinear response curve was fit, the percentage of legume cover was log-transformed. Log transformation enabled calculation of the optimum $\operatorname{EC}_{\mathrm{a}}(u)$ where legume cover was maximized and the maximum itself $(c)$. The data were not log-transformed when linear regressions were fit.

\begin{tabular}{|c|c|c|c|c|c|c|c|}
\hline Year & Stocking system & Plot & Equation & $\begin{array}{c}\text { Optimum } \\
\text { soil }^{E} C_{a}\end{array}$ & $\begin{array}{c}\text { Maximum } \\
\text { legume cover }\end{array}$ & $R^{2}$ & $\boldsymbol{P}$ \\
\hline & & & & $\mathbf{m S ~ \mathbf { m } ^ { - 1 }}$ & $\%$ & & \\
\hline \multirow[t]{12}{*}{2000} & Continuous & 1 & $\log (y+1)=-35.61+2.01 x-0.03 x^{2}$ & 38.0 & 11 & 0.87 & ** \\
\hline & & 2 & $\log (y+1)=-7.04+0.59 x-0.01 x^{2}$ & 33.1 & 14 & 0.54 & 0.10 \\
\hline & & 3 & $\log (y+1)=-11.03+0.87 x-0.01 x^{2}$ & 33.1 & 28 & 0.90 & $* * *$ \\
\hline & & 4 & & & 10 & & ns \\
\hline & Rotational & 1 & $\log (y+1)=-21.34+1.59 x-0.02 x^{2}$ & 30.5 & 18 & 0.77 & ** \\
\hline & & 2 & $\log (y+1)=-11.02+0.80 x-0.01 x^{2}$ & 35.5 & 22 & 0.66 & * \\
\hline & & 3 & $\log (y+1)=-9.29+0.87 x-0.02 x^{2}$ & 28.7 & 25 & 0.84 & ** \\
\hline & & 4 & $y=17.1-1.7 x$ & & 21 & 0.51 & $*$ \\
\hline & Nongrazed & 1 & $\log (y+1)=-21.15+1.40 x-0.02 x^{2}$ & 33.0 & 6 & 0.57 & 0.10 \\
\hline & & 2 & $\log (y+1)=-8.79+0.67 x-0.01 x^{2}$ & 30.9 & 4 & 0.47 & 0.10 \\
\hline & & 3 & $\log (y+1)=-8.10+0.67 x-0.01 x^{2}$ & 32.4 & 14 & 0.62 & 0.10 \\
\hline & & 4 & $y=24.0-2.8 x$ & & 20 & 0.94 & $* * *$ \\
\hline \multirow{12}{*}{2001} & Continuous & 1 & $\log (y+1)=-18.85+0.76 x-0.01 x^{2}$ & 55.6 & 10 & 0.89 & ** \\
\hline & & 2 & & & 11 & & ns \\
\hline & & 3 & $\log (y+1)=-16.93+0.96 x-0.01 x^{2}$ & 42.1 & 26 & 0.90 & $* * *$ \\
\hline & & 4 & $\log (y+1)=-22.05+1.13 x-0.01 x^{2}$ & 44.1 & 15 & 0.70 & * \\
\hline & Rotational & 1 & $y=-18.9+0.73 x$ & & 27 & 0.79 & $* * *$ \\
\hline & & 2 & $y=-26.6+1.00 x$ & & 48 & 0.56 & $*$ \\
\hline & & 3 & $\log (y+1)=-36.99+2.13 x-0.03 x^{2}$ & 38.0 & 30 & 0.88 & $* *$ \\
\hline & & 4 & $\log (y+1)=-7.47+0.60 x-0.01 x^{2}$ & 34.2 & 15 & 0.95 & $* * *$ \\
\hline & Nongrazed & 1 & $\log (y+1)=-15.24+0.69 x-0.01 x^{2}$ & $\mathbf{5 0 . 4}$ & 8 & 0.82 & ** \\
\hline & & 2 & & & 3 & & ns \\
\hline & & 3 & $\log (y+1)=-21.53+1.38 x-0.02 x^{2}$ & 35.5 & 17 & 0.76 & $* *$ \\
\hline & & 4 & $y=48 . .9-0.91 x$ & & 21 & $\begin{array}{l}0.10 \\
0.87\end{array}$ & $* * *$ \\
\hline
\end{tabular}

* Significant at the 0.05 probability level.

** Significant at the 0.01 probability level.

*** Significant at the $\mathbf{0 . 0 0 1}$ probability level. 
2000 and 35.5 to $55.6 \mathrm{mS} \mathrm{m} \mathrm{m}^{-1}$ in 2001 (Table 3). The optimum $\mathrm{EC}_{\mathrm{a}}$ did not show any trends of being greater or less among plots within any particular stocking system. The maximum percentage of legume cover $(c)$ at the optimum $\mathrm{EC}_{\mathrm{a}}$, however, tended to be greater among plots within the rotational stocking system than among plots within the continuous stocking system or the nongrazed system (Table 3). When nonlinear regressions were fit, the maximum ranged from 10 to $28 \%$ among plots within the continuous stocking system, 15 to $30 \%$ among plots within the rotational stocking system, and 4 to $17 \%$ among plots within the nongrazed system.

A nonlinear response curve fit the relationship between the percentage of legume cover and soil $\mathrm{EC}_{\mathrm{a}}$ across the plots within each stocking system when soil $\mathrm{EC}_{\mathrm{a}}$ was standardized within each pasture replicate in 2000 and 2001 (Fig. 2). The nonlinear response curve, fit across the mean of each 2000 soil $\mathrm{EC}_{\mathrm{a}}$ class of the four plots, explained 23 to $38 \%$ of legume cover variation. The optimum soil $\mathrm{EC}_{\mathrm{a}}$ in 2000, of which legume cover was maximized, was 5.9 within the continuous stocking system, 4.1 in the nongrazed system, and 3.8 in the rotational stocking system. The maximum legume cover at the optima was 17,13 , and $9 \%$ within the rotational, continuous, and nongrazed systems, respectively (Fig. 2).

The nonlinear relationship between the percentage of legume cover and standardized soil $\mathrm{EC}_{\mathrm{a}}$ measured in 2000 was similar to the relationship that occurred when soil $\mathrm{EC}_{\mathrm{a}}$ was measured and standardized in 2001 despite the different absolute soil $\mathrm{EC}_{\mathrm{a}}$ values from year to year. The nonlinear response curve fit across the mean of each 2001 soil $\mathrm{EC}_{\mathrm{a}}$ class of the four plots explained 25 to $42 \%$ of legume cover variation (Fig. 2). The optimum soil $\mathrm{EC}_{\mathrm{a}}$ in 2001, of which legume cover was maximized, was 6.0 within the continuous stocking system, 4.2 in the nongrazed system, and 4.0 in the rotational stocking system. The maximum legume content at the optima was 14,12 , and $7 \%$ within the rotational, continuous, and nongrazed systems, respectively (Fig. 2).

\section{Apparent Soil Electrical Conductivity and Dominant Grasses}

The dominant grasses in the pastures also showed relationships to soil $\mathrm{EC}_{\mathrm{a}}$. The percentage of smooth brome cover in the pastures decreased as soil $\mathrm{EC}_{\mathrm{a}}$ measured in 2000 and 2001 increased. The decline was linear

\section{Soil $\mathrm{EC}_{\mathrm{a}}$ measured in 2000}
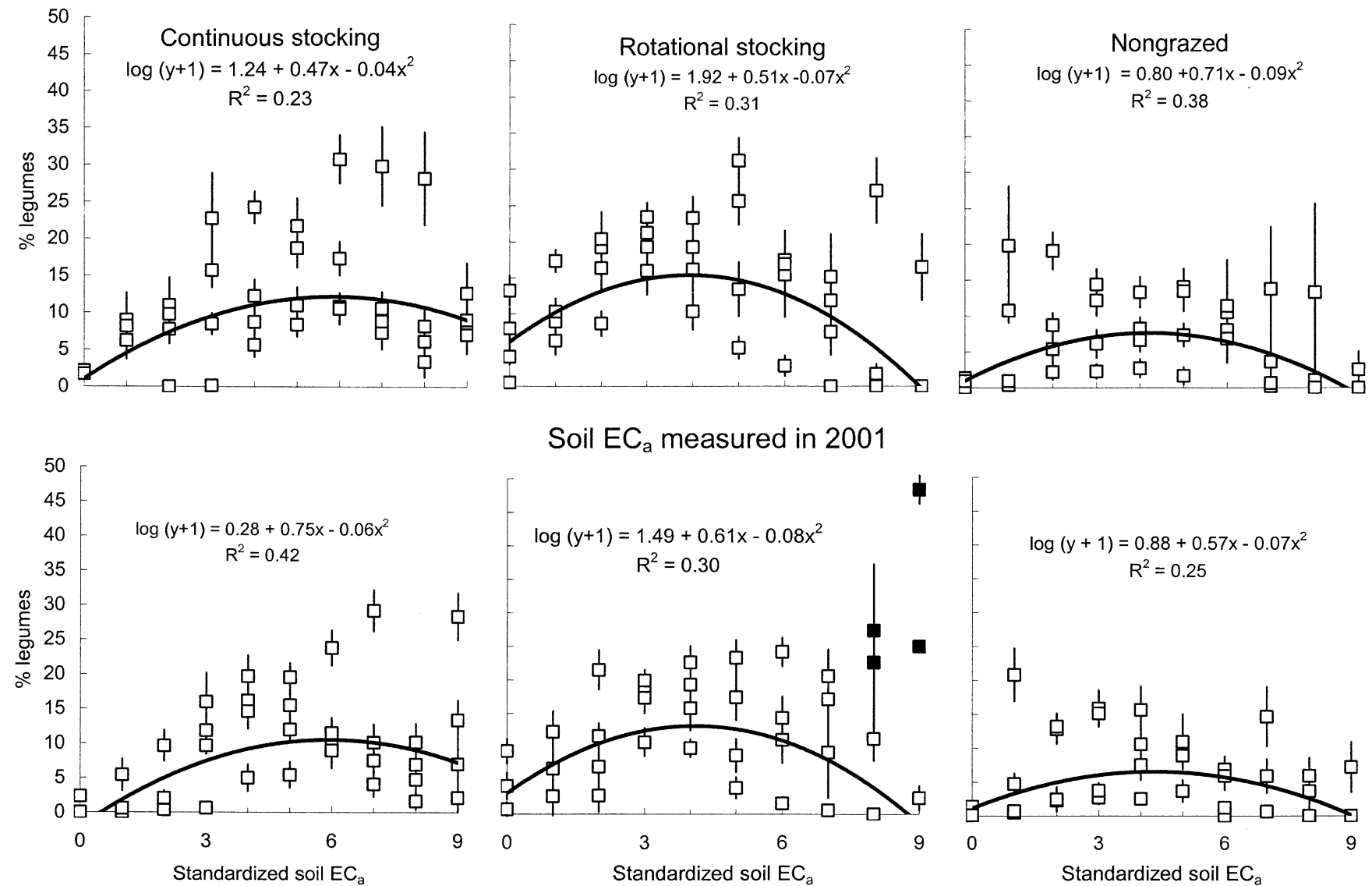

Soil EC $\mathrm{E}_{\mathrm{a}}$ measured in 2001
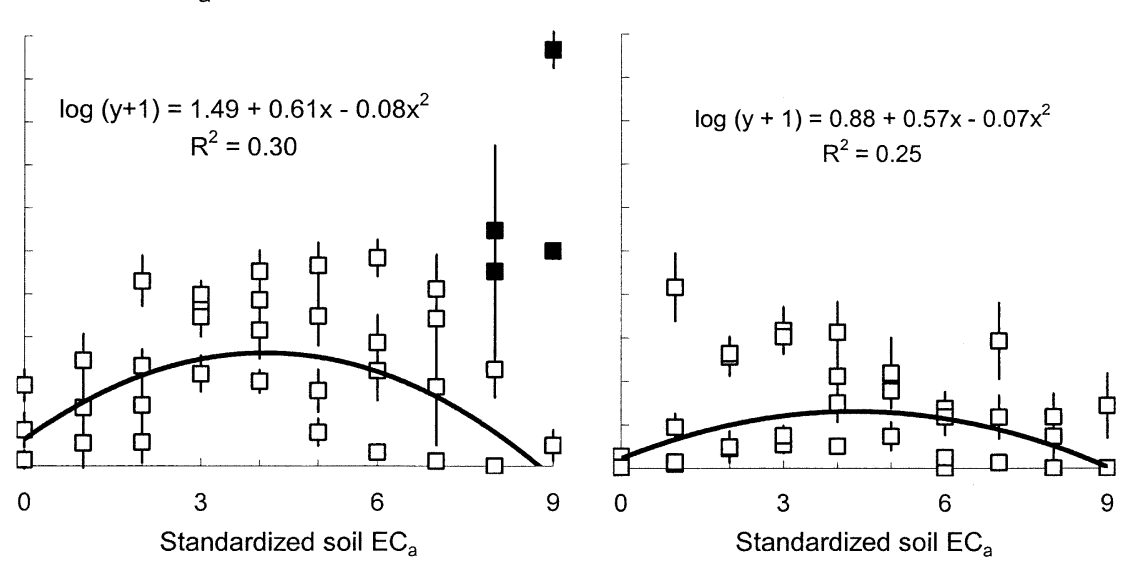

Fig. 2. Nonlinear relationship between the percentage of legume cover and apparent soil electrical conductivity $\left(\mathrm{EC}_{\mathrm{a}}\right)$ standardized within pastures at Rhodes, IA. Soil EC $\mathrm{E}_{\mathrm{a}}$ was measured on 28 July 2000 and 2 Aug. 2001 and standardized by year. Standardization involved dividing the range of absolute soil $\mathrm{EC}_{\mathrm{a}}$ values within each pasture replicate $(n=4)$ into 10 classes and ranking these from 0 to 9. Legume cover was averaged within each $\mathbf{E C}_{\mathrm{a}}$ class of the four plots of each stocking system. Some $\mathbf{E C}_{\mathrm{a}}$ classes were not represented within all four plots of each stocking system $(n \approx 40)$. Points and bars represent the mean \pm standard error. Before fitting the nonlinear response curve, the legume cover data were log-transformed. Additional outliers, represented as $\square$ points, within the rotational stocking system of year 2001, were removed before analysis. 

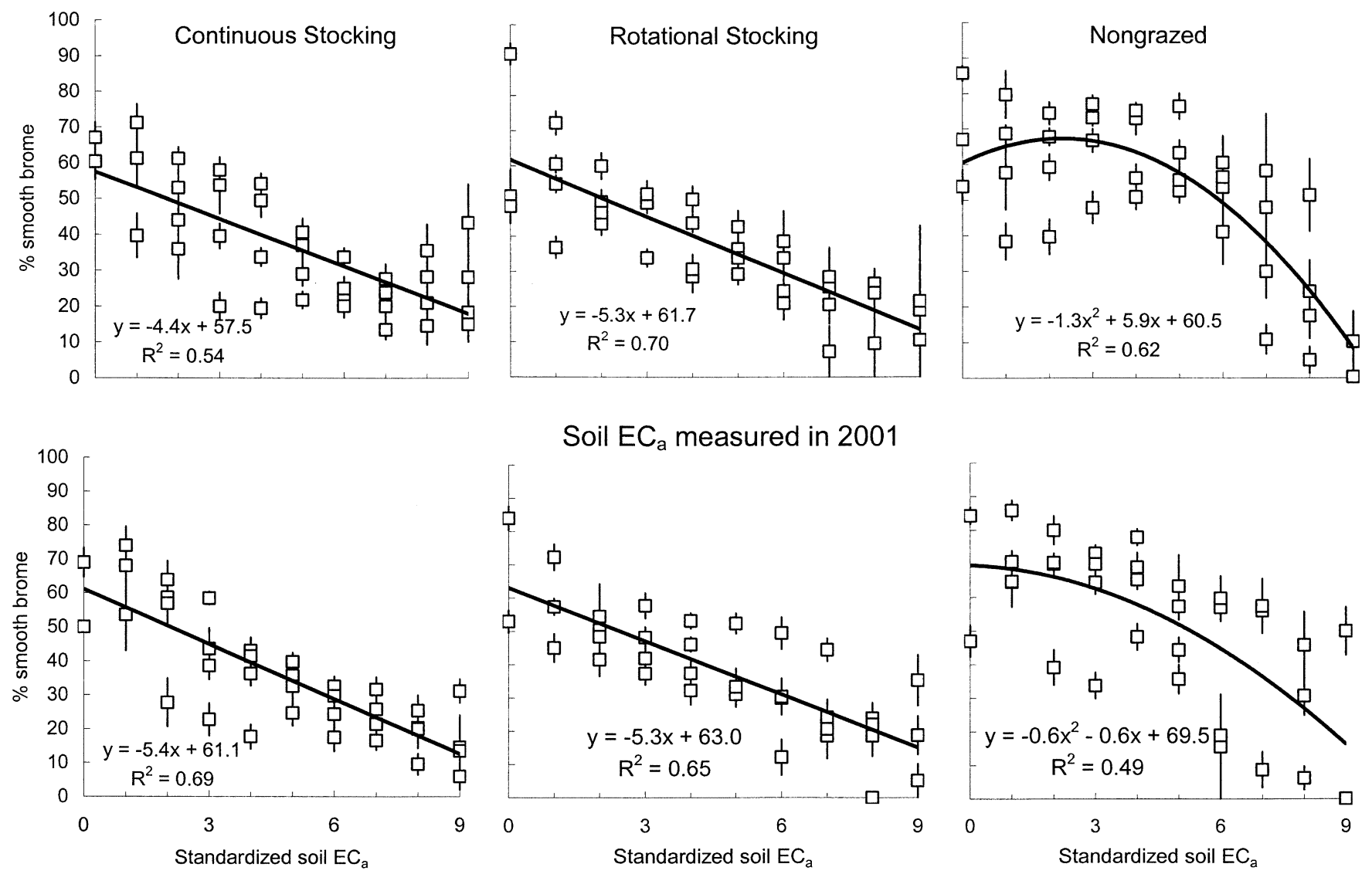

Fig. 3. Negative relationship between the percentage cover of smooth brome (Bromus inermis Leyss.) and apparent soil electrical conductivity $\left(\mathbf{E C}_{\mathrm{a}}\right)$ standardized within pastures at Rhodes, IA. Soil $\mathbf{E C}_{\mathrm{a}}$ was measured on 28 July 2000 and 2 Aug. 2001 and standardized by year. Standardization involved dividing the range of absolute soil $\mathrm{EC}_{\mathrm{a}}$ values within each pasture replicate $(n=4)$ into 10 classes and ranking these from 0 to 9. Smooth brome cover was averaged within each $\mathbf{E C}_{\mathrm{a}}$ class of four plots of each stocking system. Some $\mathbf{E C}_{\mathrm{a}}$ classes were not represented within all four plots of each stocking system $(n \approx 40)$. Points and bars represent the mean \pm standard error.

within the rotational and continuous stocking systems and nonlinear in the nongrazed system (Fig. 3). An opposite response occurred for reed canarygrass as its cover increased as $\mathrm{EC}_{\mathrm{a}}$ measured in 2000 and 2001 increased (Fig. 4). The slope of the relationship between reed canarygrass cover and soil $\mathrm{EC}_{\mathrm{a}}$ was greater within the nongrazed system than within the rotational and continuous stocking systems (Fig. 4).

\section{DISCUSSION}

Legumes, as a percentage of pasture cover, are most successful at 15 to $20 \%$ slopes. Harmoney et al. (2001) showed that legumes were $161 \mathrm{~g} \mathrm{~kg}^{-1} \mathrm{DM}$ on backslope landscape positions compared with $62 \mathrm{~g} \mathrm{~kg}^{-1} \mathrm{DM}$ on summits and $7 \mathrm{~g} \mathrm{~kg}^{-1} \mathrm{DM}$ on toeslopes. We showed that slope, when derived from a DEM, explained 22 to $75 \%$ of legume cover variation in these pastures. Slope data derived from a DEM have been useful in discriminating between spatial and temporal clusters of corn yields along landscapes in Iowa (Jaynes et al., 2003). Our data suggest that information about slope would be useful for site-specific management of southeastern Iowa pastures.

Legumes establish and persist on landscape positions with 15 to $20 \%$ slopes but fail at positions with lesser slopes because competition from grasses limits seedling survival of legumes on positions with lesser slopes (Guretzky et al., 2004). Backslope positions, which averaged $15 \%$ slope, produced 0.5 and $2.4 \mathrm{Mg} \mathrm{ha}^{-1}$ less grass dry matter than summit and toeslope positions, respectively (Harmoney et al., 2001). Soil organic matter and A-horizon thickness tends to be proportional to slope. Soils on steep slopes tend to be thin and have low organic matter in the A-horizon (Birkeland, 1999). Slope was negatively correlated with organic matter content and corn and soybean grain yields in Illinois and Indiana (Kravchenko and Bullock, 2000). Along a toposequence in Colorado, DEM-derived slope was negatively correlated with A-horizon thickness, extractable P, and organic matter (Moore et al., 1993).

Soil moisture also tends to be greater on less-sloping positions. Across agricultural landscapes in Illinois, somewhat poorly drained and poorly drained soils were dominant at the lowest slopes, and as slope increased, the occurrence of well-drained and moderately well-drained soils increased (Kravchenko et al., 2002). Spatial variation in soil water availability, related to soil depth and drainage patterns, was the primary mechanism causing topographic differences in plant community composi- 


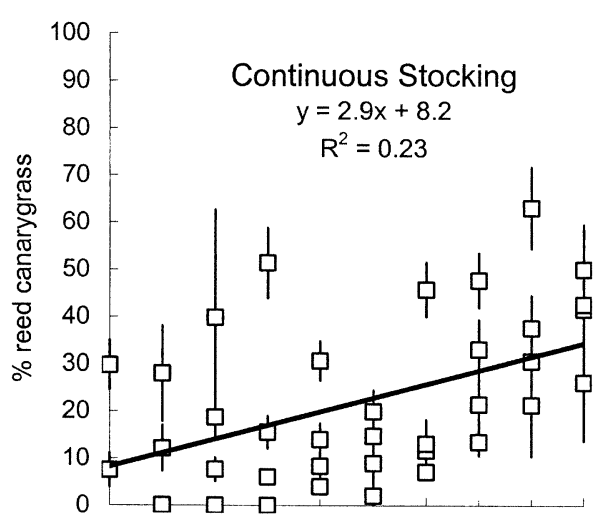

\section{Soil EC $\mathrm{C}_{\mathrm{a}}$ measured in 2000}
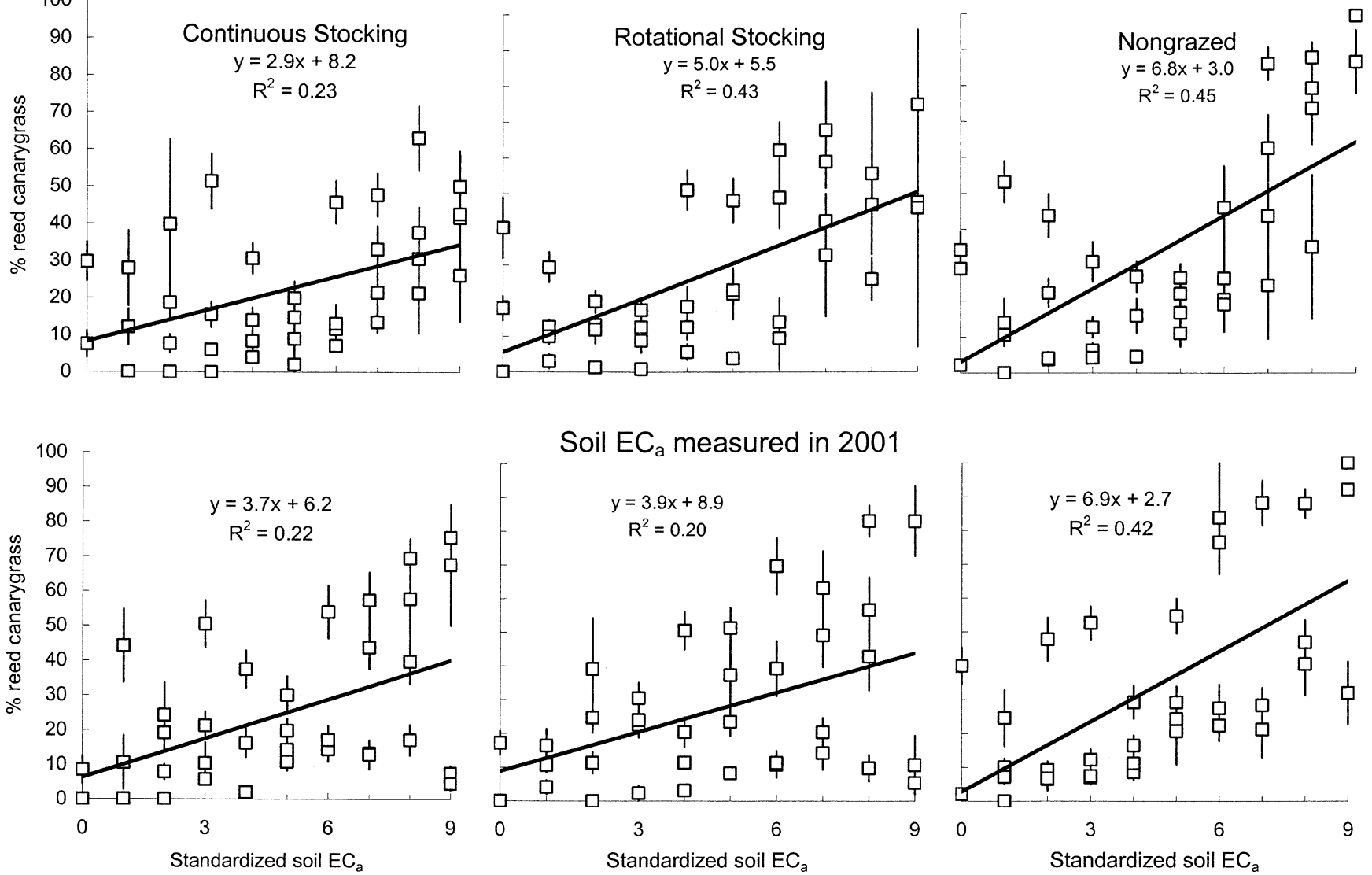

Fig. 4. Positive relationship between the percentage cover of reed canarygrass (Phalaris arundinacea $\left.\mathrm{L}_{\text {. }}\right)$ and apparent soil conductivity $\left(\mathrm{EC}_{\mathrm{a}}\right)$ standardized within pastures at Rhodes, IA. Soil $\mathbf{E C}_{\mathrm{a}}$ was measured on 28 July 2000 and 2 Aug. 2001 and standardized by year. Standardization involved dividing the range of absolute soil $\mathrm{EC}_{\mathrm{a}}$ values within each pasture replicate $(n=4)$ into 10 classes and ranking these from 0 to 9. Reed canarygrass cover was averaged within each $\mathbf{E C}_{\mathrm{a}}$ class of four plots of each stocking system. Some $\mathbf{E C}_{\mathrm{a}}$ classes were not represented within all four plots of each stocking system $(n \approx 40)$. Points and bars represent the mean \pm standard error.

tion and aboveground productivity in tallgrass prairie in Kansas (Knapp et al., 1993). Greater soil moisture enhances productivity and competitiveness of existing grasses and limits the availability of light to legume seedlings in pastures (Groya and Sheaffer, 1981).

Reports on the influence of topographic position and slope on $\mathrm{N}$ availability across landscapes have been inconsistent. Nitrogen mineralization was up to five times greater on upland sites than lowland sites and was inversely related to aboveground biomass yields of tallgrass prairie in Kansas (Turner et al., 1997). In contrast, $\mathrm{N}$ mineralization and total $\mathrm{N}$ content of biomass followed similar patterns as biomass itself, increasing from upper-slope positions to lower-slope positions in the shortgrass steppe of Colorado (Schimel et al., 1985). Mineralization, expressed as a percentage of total N, however, was greater on summits than toeslope positions, suggesting that despite greater $\mathrm{N}$ availability on toeslope positions, turnover of $\mathrm{N}$ is greater on summit and backslope positions (Schimel et al., 1985).

Forage producers also can use soil $\mathrm{EC}_{\mathrm{a}}$ mapping to identify sites where legumes will be successful in pastures. We found that the optimum soil $\mathrm{EC}_{\mathrm{a}}$ at which legumes were maximized $(c)$ and the maximum itself (u) varied among plots within each stocking system.
The relationship between legume content and soil $\mathrm{EC}_{\mathrm{a}}$, however, tended to be nonlinear (Table 3), and when $\mathrm{EC}_{\mathrm{a}}$ was standardized within each pasture, a nonlinear response curve explained 23 to $42 \%$ of the percentage of legume cover across the plots (Fig. 2). In most plots, legumes tolerated a range of $\mathrm{EC}_{\mathrm{a}}$ and were greatest at intermediate $\mathrm{EC}_{\mathrm{a}}$ values. These patterns were consistent regardless of the year soil $\mathrm{EC}_{\mathrm{a}}$ was measured (Fig. 2).

Apparent soil electrical conductivity is a field-based measure of the electrical conductivity of bulk soil and is primarily a function of soil salinity, saturation percentage, water content, and bulk density (Corwin and Lesch, 2003). Soil $\mathrm{EC}_{\mathrm{a}}$ data are easily obtained by sensors that use either electrical resistivity or electromagnetic induction (Corwin and Lesch, 2003; Sudduth et al., 2003). Patterns of soil $\mathrm{EC}_{\mathrm{a}}$ across a field reflect soil properties that are often correlated with crop productivity and other ecological properties (Johnson et al., 2001; Kitchen et al., 1999), and these patterns are stable across time (Mueller et al., 2003). Mapping of $\mathrm{EC}_{\mathrm{a}}$ may also minimize expenses by reducing the number of soil samples required to characterize soil property variation throughout a field (Johnson et al., 2001; Sudduth et al., 2003).

We selected soil $\mathrm{EC}_{\mathrm{a}}$ as a determining factor for legume distribution because it is closely associated with 
soil properties that affect the productivity of grasses in pastures. Legumes do not respond directly to soil $\mathrm{EC}_{\mathrm{a}}$. Their distribution in these pastures is affected by competition from cool-season grasses (Guretzky et al., 2004; Harmoney et al., 2001). In eastern Colorado, high soil $\mathrm{EC}_{\mathrm{a}}$ indicated areas of erosion; was positively correlated with bulk density, percentage clay, and $\mathrm{pH}$; and was negatively correlated with crop productivity (Johnson et al., 2001). An opposite response occurred in Kentucky fields as soil $\mathrm{EC}_{\mathrm{a}}$ decreased as factors that limit rooting depth and crop productivity, such as depth to clay increase, depth to bedrock, and depth to fragipan, increased (Mueller et al., 2003). We did not attempt to calibrate $\mathrm{EC}_{\mathrm{a}}$ to soil properties because earlier attempts at characterizing the relationship of landscape positions with soil properties in these pastures were largely unsuccessful; summit, backslope, and toeslope positions were similar for several properties, including soil $\mathrm{P}$ and $\mathrm{K}$, $\mathrm{pH}$, organic matter, and texture in these pastures (Harmoney, 1999).

A review of studies of gently rolling landscapes in Iowa and other areas of the Midwest has shown that high $\mathrm{EC}_{\mathrm{a}}$ values often are positively correlated with higher soil water contents and lower elevations. Along hillslopes in eastern South Dakota, lower elevations consistently had greater $\mathrm{EC}_{\mathrm{a}}$ values and soil water contents than higher elevations (Nugteren et al., 2000). Apparent soil electrical conductivity was negatively correlated with well-drained and moderately well-drained soils and positively correlated with somewhat poorly drained and poorly drained soils in Illinois crop fields (Kravchenko et al., 2002). In north-central Iowa, $\mathrm{EC}_{\mathrm{a}}$ was greatest on toeslope positions where poorly drained soils predominated and lowest on summits and shoulders where well-drained soils were most common (Jaynes et al., 2003).

We conclude that moisture availability likely drove landscape patterns in soil $\mathrm{EC}_{\mathrm{a}}$ and grass productivity in these pastures. Across the pastures, greater soil $\mathrm{EC}_{\mathrm{a}}$ was associated with lower elevations (Table 2). Elevation is lowest on toeslope positions, albeit where grass productivity and soil $\mathrm{EC}_{\mathrm{a}}$ are greatest. Soil $\mathrm{EC}_{\mathrm{a}}$ was also positively correlated with the wetness index and flow accumulation, hydrologic indicators of where water and sediment accumulates over landscapes (Burrough and McDonnell, 1998; Moore et al., 1993). The relationship of $\mathrm{EC}_{\mathrm{a}}$ with elevation, slope, flow accumulation, and wetness index was similar regardless of the year $\mathrm{EC}_{\mathrm{a}}$ was measured (Table 2).

Landscape patterns in moisture availability contribute to a dominance of grasses on summits and toeslopes, consequently where soil $\mathrm{EC}_{\mathrm{a}}$ is low and high, respectively. We found that soil $\mathrm{EC}_{\mathrm{a}}$ successfully explained the distribution of the dominant grasses in these pastures: smooth brome and reed canarygrass. Where soil moisture is greatest, reed canarygrass dominates the vegetation. In areas where moisture is lowest, smooth brome dominates.

Grazing increases legumes, as a percentage of pasture cover, at 15 to $20 \%$ slopes and intermediate soil $\mathrm{EC}_{\mathrm{a}}$ values. At these slopes and $\mathrm{EC}_{\mathrm{a}}$ values, rotationally and continuously stocked pastures had a greater percentage of legumes than nongrazed pastures. Legume cover was similar among stocking systems when slopes were $<10 \%$ and $\mathrm{EC}_{\mathrm{a}}$ values were either low or high. Large grazing animals create heterogeneity in plant communities through patchy grazing (Adler et al., 2001; Cid and Brizuela, 1998), trampling of vegetation and soils (Hartnett et al., 1996), and the excretion of manure and urine (Steinauer and Collins, 1995). In the absence of such disturbances, competitive interactions may favor the dominant grasses and decrease species diversity in grasslands (Collins, 1987).

Rotational stocking achieved the greatest percentage of legume cover in the pastures. Stocking rates were similar among the continuously and rotationally stocked systems; however, rest periods were longer in the rotationally stocked system. Longer rest periods allowed the legumes to recover from defoliation, flower, and set seed and may have encouraged legume recruitment from the seedbank. In northeastern U.S. pastures, legumes consisted of a greater proportion of total dry matter production in pastures when rest periods were longer and grazing heights taller because upright-growing legumes such as alfalfa and red clover were favored (Carlassarre and Karsten, 2002). Continuous stocking creates and maintains patches in vegetation that differ in degrees of utilization (Cid and Brizuela, 1998). White clover, a prostrate-growing, grazing-tolerant legume, is adapted to highly utilized patches but contributes less to total dry matter production than taller legumes in pasture swards (Carlassarre and Karsten, 2002).

The benefits of sowing legumes on sites with 15 to $20 \%$ slopes or intermediate $\mathrm{EC}_{\mathrm{a}}$ values are numerous. Establishment of legumes on these sites has the potential to improve dry matter yields compared with grassonly pastures (Harmoney et al., 2001). Through a symbiotic relationship with rhizobium bacteria, legumes fix atmospheric $\mathrm{N}_{2}$, allowing them to be virtually self-sufficient for N (Heichel, 1985). The decomposition of legume leaf residues, roots, and nodules also increases soil $\mathrm{N}$ and reduces $\mathrm{N}$ requirements of grasses (Heichel et al., 1985). Legumes are also greater in crude protein than grasses, and their incorporation with grasses improves herbage quality of forage mixtures (Harmoney, 1999; Sleugh et al., 2000).

In conclusion, we characterized the topographic variability of several southeastern Iowa pastures using soil $\mathrm{EC}_{\mathrm{a}}$ mapping and DEMs. The distribution of legumes in these pastures was closely associated with gradients of slope and $\mathrm{EC}_{\mathrm{a}}$. We recommend that legumes be seeded where soil $\mathrm{EC}_{\mathrm{a}}$ values are intermediate or slopes are 15 to $20 \%$. Rotational stocking systems will encourage the persistence and production of legumes at these sites by reducing competition from smooth brome and reed canarygrass. If the spatial tools are unavailable or landscape positions are easily differentiated, legumes should be seeded on backslope landscape positions. On backslopes, where slopes are greatest and soil $\mathrm{EC}_{\mathrm{a}}$ intermediate, legumes will increase soil $\mathrm{N}$ availability, improve herbage yields and quality, and optimize the seasonal distribution of dry matter and nutrients in pastures. 


\section{REFERENCES}

Adler, P.B., D.A. Raff, and W.K. Lauenroth. 2001. The effect of grazing on the spatial heterogeneity of vegetation. Oecologia 128: 465-479.

Birkeland, P.W. 1999. Soils and geomorphology. 3rd ed. Oxford Univ. Press, New York.

Burrough, P.A., and R.A. McDonnell. 1998. Principles of geographical information systems. Oxford Univ. Press, Oxford.

Carlassarre, M., and H.D. Karsten. 2002. Species contribution to seasonal productivity of a mixed pasture under two sward grazing height regimes. Agron. J. 94:840-850.

Cid, M.S., and M.A. Brizuela. 1998. Heterogeneity in tall fescue pastures created and sustained by cattle grazing. J. Range Manage. 51:644-649.

Collins, S.L. 1987. Interaction of disturbances in tallgrass prairie: A field experiment. Ecology 68:1243-1250.

Corwin, D.L., and S.M. Lesch. 2003. Application of soil electrical conductivity to precision agriculture: Theory, principles, and guidelines. Agron. J. 95:455-471.

Daubenmire, R.F. 1968. Plant communities: A textbook of plant synecology. Harper \& Row, New York.

Groya, F.L., and C.C. Sheaffer. 1981. Establishment of sod-seeded alfalfa at various levels of soil moisture and grass competition. Agron. J. 73:560-565.

Guretzky, J.A., K.J. Moore, A.D. Knapp, and E.C. Brummer. 2004. Emergence and survival of legumes seeded into pastures varying in landscape position. Crop Sci. (in press).

Harmoney, K.R. 1999. Legume establishment and persistence at sites varying in landscape position, grazing method, and soil characteristics. Ph.D. diss. Iowa State Univ., Ames.

Harmoney, K.R., K.J. Moore, E.C. Brummer, C.L. Burras, and J.R. George. 2001. Spatial legume composition and diversity across seeded landscapes. Agron. J. 93:992-1000.

Hartnett, D.C., K.R. Hickman, and L.E. Fischer Walter. 1996. Effects of bison grazing, fire, and topography on floristic diversity in tallgrass prairie. J. Range Manage. 49:413-420.

Heichel, G.H. 1985. Symbiosis: Nodule bacteria and leguminous plants. p. 64-71. In M.E. Heath et al. (ed.) Forages: The science of grassland agriculture. 4th ed. Iowa State Univ. Press, Ames.

Heichel, G.H., C.P. Vance, D.K. Barnes, and K.I. Henjum. 1985. Dinitrogen fixation and $\mathrm{N}$ and dry matter distribution during 4 year stands of birdsfoot trefoil and red clover. Crop Sci. 25:101-105.

Iowa State University Extension. 1998. Pasture management guide for livestock producers. Pm-1713. Iowa State Univ. Ext., Ames.

Jaynes, D.B., T.C. Kaspar, T.S. Colvin, and D.E. James. 2003. Cluster analysis of spatiotemporal corn yield patterns in an Iowa field. Agron. J. 95:574-586.

Johnson, C.K., J.W. Doran, H.R. Duke, B.J. Wienhold, K.M. Eskridge, and J.F. Shanahan. 2001. Field-scale electrical conductivity map- ping for delineating soil condition. Soil Sci. Soc. Am. J. 65: 1829-1837.

Kitchen, N.R., S.T. Drummond, E.D. Lund, K.A. Sudduth, and G.W. Buchleiter. 2003. Soil electrical conductivity and topography related to yield for three contrasting soil-crop systems. Agron. J. 95:483-495.

Kitchen, N.R., K.A. Sudduth, and S.T. Drummond. 1999. Soil electrical conductivity as a crop productivity measure for claypan soils. J. Prod. Agric. 12:607-617.

Knapp, A.K., J.T. Fahnestock, S.P. Hamburg, L.J. Statland, T.R. Seastedt, and D.S. Schimel. 1993. Landscape patterns in soil-water relations and primary production in tallgrass prairie. Ecology 74 : 549-560.

Kravchenko, A.N., G.A. Bollero, R.A. Omonode, and D.G. Bullock. 2002. Quantitative mapping of soil drainage classes using topographical data and soil electrical conductivity. Soil Sci. Soc. Am. J. 66:235-243.

Kravchenko, A.N., and D.G. Bullock. 2000. Correlation of corn and soybean grain yield with topography and soil properties. Agron. J. 92:75-83.

Moore, I.D., P.E. Gessler, G.A. Nielsen, and G.A. Peterson. 1993. Soil attribute prediction using terrain analysis. Soil Sci. Soc. Am. J. 57:443-452.

Mueller, T.G., N.J. Hartsock, T.S. Stombaugh, S.A. Shearer, P.L. Cornelius, and R.I. Barnhisel. 2003. Soil electrical conductivity map variability in limestone soils overlain by loess. Agron. J. 95:496-507.

Nugteren, W.A., D.D. Malo, T.E. Schumacher, J.A. Schumacher, C.G. Carlson, D.E. Clay, S.A. Clay, K.J. Dalsted, and M.M. Ellsbury. 2000. Hillslope chronosequences of electromagnetic induction readings as influenced by selected soil properties. In W.E. Larson (ed.) Precision agriculture [CD-ROM]. Proc. Int. Conf., 5th, Minneapolis, MN. 16-19 July 2000. ASA, CSSA, and SSSA, Madison, WI

Schimel, D., M.A. Stillwell, and R.G. Woodmansee. 1985. Biogeochemistry of $\mathrm{C}, \mathrm{N}$, and $\mathrm{P}$ in a soil catena of the shortgrass steppe. Ecology 66:276-282.

Sleugh, B., K.J. Moore, J.R. George, and E.C. Brummer. 2000. Binary legume-grass mixtures improve forage yield, quality, and seasonal distribution. Agron. J. 92:24-29.

Steinauer, E.M., and S.L. Collins. 1995. Effects of urine deposition on small-scale patch structure in prairie vegetation. Ecology 76: $1195-1205$.

Sudduth, K.A., N.R. Kitchen, G.A. Bollero, D.G. Bullock, and W.J Wiebold. 2003. Comparison of electromagnetic induction and direct sensing of soil electrical conductivity. Agron. J. 95:472-482.

ter Braak, C.J., and C.W.N. Looman. 1995. Regression. p. 29-77. In R.H.G. Jongman et al. (ed.) Data analysis in community and landscape ecology. Cambridge Univ. Press, Cambridge, UK.

Turner, C.L., J.M. Blair, R.J. Schartz, and J.C. Neel. 1997. Soil N and plant responses to fire, topography, and supplemental $\mathrm{N}$ in tallgrass prairie. Ecology 78:1832-1843.

Van Soest, P.J.1982. Nutritional ecology of the ruminant. O\&B Books, Corvallis, OR. 